MARKO STAMENKOVIĆ

Univerzitet u Gentu, Belgija

DOI 10.5937/kultura1237144S

UDK 75.044

originalan naučni rad

\title{
CITANJE AMBASADORA
}

\section{FUNDAMENTALNI NARCIZAM, PONIŠTENJE SUBJEKTA I JOŠ JEDNA SKICA ZA AUTODESTRUKTIVNU FUNKCIJU POGLEDA}

Sažetak: Ovaj tekst nastao je u kontekstu preliminarnih istraživanja autora na terenu analize slike, $u$ kojem funkcija pogleda ima presudan značaj u operaciji "poništenja subjekta" posmatranja. Tekst polazi od poznatih teorijskih i istorijsko-umetničkih tumačenja slike Ambasadori, kojom Hans Holbajn Mlađi, u prvoj polovini šesnaestog veka, suprotstavlja ne samo optičku, nelinearnu perspektivu dominantnoj centralnoj geometrijskoj perspektivi, nego i jednog geometrijskog (pravolinijskog, straight) subjekta drugačijem subjektu: optičkom, eks-centričnom, skopičkom. Namera teksta je da, i pet vekova kasnije, još jednom probudi statičnog, fiksiranog i fokusiranog posmatrača (simptoma i glavnog protagonistu isto tako statične, fiksirane i fokusirane kulture pogleda) $u$ cilju zauzimanja radikalno drugačije pozicije posmatranja. Zašto? Zato što se izmeštanjem Holbajnovog posmatrača iz pozicije statusa quo (decentriranjem njegovog pogleda, optičkim pomeranjem iz udobnosti fiksirane tačke opažanja, kao i njegovim fizičkim pomeranjem) tako decentralizovanom, "ekscentričnom" posmatraču nudi prilika da se još jednom, i svaki put iznova, aktivno uključi u istorijska pomeranja ka drugačijoj kulturi pogleda. Ovde se pod drugačijom kulturom pogleda podrazumeva ona kultura zbog koje, konstantnim prekoračenjem granica nekulture pogleda, imamo razloga da verujemo u mogućnost drugačijeg sveta, drugačijeg poimanja sveta slike i drugačijeg poimanja slike sveta - drugačijeg od onog u kojem, poput zarobljenika, želi da nas zadrži konzervativna, atavistička, samodovoljna, patrijarhalna i "patriotska" kultura jednog okorelo centralističkog, tvrdoglavo frontalnog $i$ neprikosnoveno pravovernog ("straight") pogleda na svet.

Ključne reči: (ne)kulture pogleda, poništenje subjekta, narcizam gledanja, Holbajn 


\section{MARKO STAMENKOVIĆ}

\section{Uvod: princip kontrasta ${ }^{l}$}

Oni jednostavno ostaju uspravni oko praznine koja ih čini čudno samim, i bliskim.

Julia Kristeva $^{2}$

Dve su muške figure predstavljene na slici Ambasadori ${ }^{3}$ : jedna sa desne, druga sa leve strane otvorenog dvospratnog ormarića. Obe police ormarića, gornja (pokrivena ćilimom) i donja (otkrivena), nose raznovrsne predmete među kojima se mogu prepoznati određeni instrumenti (muzički i naučni) i knjige. Muškarci stoje na dekorativnom podu. Tamo, između njihovih nogu, u prvi plan izbija nekakav bezobličan predmet, koji postavljen pod uglom u odnosu na nivo poda baca skoro neprimetnu senku. Pozadinu zatvara zelena zavesa - samo se u gornjem levom uglu u odnosu na nas nazire vertikalna metalno-siva linija, u kojoj prepoznajemo uspravnu anatomsku figuru koja izgleda kao da lebdi u vazduhu. Muškarci, u punoj veličini, frontalno okrenuti ka nama, stoje mirno, uspravni, nepomični, suzdržani, gotovo nalik muzejskim voštanim figurama. Onaj sa leve strane u odnosu na nas zauzima malo opušteniju pozu, shvaćenu u smislu klasičnog kontraposta, sa blago savijenom nogom u levom kolenu, dok je drugi zaustavljen u disciplinovanom stavu. Obojica se oslanjaju laktom na gornju policu kredenca.

Uočljiva je razlika u njihovoj odeći. Muškarac levo odeven je raskošno i ostavlja utisak samodopadljivog bogataša koji poznaje estetske norme: on nosi sjajnu purpurnu košulju i crni ogrtač opervažen svetlim krznom, koji, otkriven, pokazuje donji sloj garderobe vezan upadljivom mašnom oko struka - nešto nalik crnoj suknji koja mu otkriva nožne listove i obuću, jednostavnu i takođe crnu. Desnom rukom drži predmet koji bi mogao biti bodež - to su, u svakom slučaju, korice za neko oružje (jer ono što

1 Prvobitna verzija ovog teksta nastala je tokom prve polovine 2003. godine u kontekstu mog rada na diplomskoj tezi pod naslovom Koncept pogleda $i$ čitanje slike, odbranjenoj u junu iste godine na Katedri za istoriju moderne umetnosti Odeljenja za istoriju umetnosti Filozofskog fakulteta Univerziteta u Beogradu. Ovaj tekst, neobjavljen do sada, kao i ukupan rad na svojoj diplomskoj tezi (takođe neobjavljenoj), smatram jednim od ključnih elemenata za formiranje teorijskih uslova u kojima je septembra 2011. godine započeto moje istraživanje u okviru doktorskih studija na Filozofskom fakultetu Univerziteta u Gentu (Belgija), pod nazivom Kulture suicida. Teorije i prakse radikalnog povlačenja - Transnacionalna kulturalna i medijska paradigma (2001-2011).

2 Kristeva J., Crno sunce. Depresija i melanholija, Novi Sad 1994, str. 169.

3 Pogledati: Holbajn H., Ambasadori, Nacionalna galerija, London. The National Gallery, Hans Holbein the Younger, The Ambassadors, 27.09.2012, http://www.nationalgallery.org.uk/paintings/hans-holbein-the-younger-theambassadors 
se možda nalazi u njima nedostupno je našem pogledu), na kojima je izgraviran broj dvadesetdevet. Tom istom rukom on kao da blago pomera ogrtač u stranu i ne dozvoljava da mu prekrije odeću ispod: kao da što više želi da istakne dugačak lanac koji mu visi oko vrata i završava se velikim medaljonom, sa figuralnom predstavom u sredini. Za razliku od njega, muškarac desno levom rukom primiče svoj ogrtač uz telo i kao da se zakopčava, ne ostavljajući mogućnost da se prepozna ostatak njegove odeće ispod. Telo ovog drugog muškarca toliko je zatvoreno tkaninom odeće koja se spušta do poda, da mu čak i stopala ostaju pokrivena i tako sakrivena od nas. On je obučen mnogo skromnije: njegova jednostavna, gotovo monohromna odora, dekorisana neupadljivim linearnim motivom koji se za nijansu razlikuje od dominantne braon boje ogrtača, opervažena tamnom dlakom, $\mathrm{u}$ potpunosti mu zatvara telo, poput nekakvog oklopa, i ostavlja tek malo otvora pri vrhu, gde vidimo crnu košulju sa belim okovratnikom. Knjiga na koju se naslanja ima ispisan broj dvadesetpet. U desnoj ruci nosi nešto nalik rukavicama. Čak i njegove šake, savijene dok pridržava sasvim lake predmete, sakrivaju mu skoro sve prste i deluju zgrčenije i napetije u odnosu na šake muškarca levo: njegovi dugi prsti otkriveni su u opuštenom gestu i sasvim odaju njegov ležeran stav, toliko da možemo pretpostaviti da su čak i korice bodeža, na koje samo naslanja svoje prste, zapravo - prazne (osim u slučaju da su nečim prikačene za njegov ogrtač). Na glavama nose slične crne kape, ali ne sasvim iste: ovom levo ona, data kao iz profila, izgleda poput pljosnate pečurke, sa jedva primetnom smeđom dekoracijom u gornjem delu; onom desno kapa se ističe trostranim špicevima i sasvim je bez ukrasa. Obojica nose bradu i brkove, s tim što na osobi levo izgleda kao da je tome poklonjena veća pažnja (njegova brada deluje urednije i "modernije", kao naročito oblikovana i začešljana po sredini), dok kod druge osobe, mada nije zapuštena, ipak deluje prirodnije, puštana bez naznaka naročite spremnosti da njenom oblikovanju posveti veću pažnju. I lice osobe levo, mladalačko i rumeno, deluje prijatnije, negovanije; ono drugo lice, tamnoputo, izgleda bucmastije i manje prefinjeno, i stoga malo zrelije.

Opisane figure dele kompoziciju po vertikali na tri prostorna dela: levi, desni i centralni. Predmeti na policama pripadaju centralnom delu tako omeđenog prostora, ali sâm kredenac je takođe shvaćen kao horizontalno podeljen prostor: gornja i donja polica kredenca nose, po svemu sudeći, instrumente koji su dovedeni u neku međusobnu vezu, i koji se, shodno nivou koji zauzimaju, mogu isto tako razlikovati po principu kontrasta. Prva razlika koju uočavamo tiče se ćilima kojim je prekrivena samo gornja polica. Pretpostavljamo, s obzirom na dekorativnu shemu, da je orijentalnog porekla. Od predmeta na policama, 
koje lako možemo prepoznati, odmah izdvajamo globuse: onaj gornji ispunjen je podacima koji se tiču neba i nebeskih tela, dok je donji sasvim sigurno običan, zemaljski globus. Pored zemaljskog globusa vidi se jedna velika lauta, zatim jedan šestar, dve knjige (od kojih je jedna otvorena, a drugoj je među listove umetnut nekakav predmet, nalik lenjiru). Pored otvorene knjige vidimo nekoliko cevastih otvora. Ispod donje police kao da se nalazi još jedan predmet, pokriven senkom - on najviše liči na (još jednu) lautu, okrenutu "licem" prema podu. Predmeti na gornjoj polici, pored već prepoznatog nebeskog globusa i zatvorene knjige o koju se oslanja muškarac sa desne strane, teže se mogu imenovati - ono što ih povezuje i olakšava detekciju jeste merni sistem, odnosno skala podeoka kojim se svaki od njih može prihvatiti kao (1) merni instrument, (2) neka vrsta časovnika, i konačno (3) objekat naučne prirode. Budući da se nalaze na istoj polici kao i nebeski globus, pretpostavljamo da se radi o instrumentima koji se tiču astronomije. Zelena zavesa u pozadini, bogato dekorisana floralnim motivima, izvedena je od nekog teškog i verovatno skupocenog materijala. Ona zahvata čitav zadnji plan slike. Jedino partija u gornjem levom uglu, već ustanovljena kao figura u vertikalnom položaju, ostaje jedva otkrivena. Bližim zagledanjem postaje jasno da se radi o predstavi raspetog tela. Pretpostavljamo da je u pitanju tradicionalna predstava Hristovog raspeća. Pod je sasvim precizno dekorativno izveden u geometrijskoj raspodeli površine, i da nije nejasnog oblika u prednjem planu, izgledao bi možda manje zanimljiv. Ono što ovde mora biti primećeno jeste da su muškarci zauzeli sasvim različit odnos prema simetričnim dekorativnim kružnicama u nivou poda: dok muškarac levo jednom svojom nogom stupa u prostor kružnice pred sobom, drugi ostaje povučen unazad i ostavlja "svoju” kružnicu neispunjenom, praznom.

Već na denotativnom nivou jasno je da se radi o slici baziranoj na kontrastima. Princip kontrasta izveden je rekonstrukcijom celovitosti slike na osnovu ponuđenih fragmentarnih indikacija. Time smo, skidanjem prvog vela sa slike koju analiziramo, obezbedili sebi pravo da, ulaženjem u telo slike, postanemo jedan od njenih protagonista, da budemo deo događaja koji analiziramo: savladana je prva barijera između slike i posmatrača i obezbeđeno nam je pravo na aktivnu participaciju u slici, u ulozi naratora koja nam je time potvrđena. Ovim su, međutim, samo otškrinuta vrata značenju koje slika nudi: da bismo ga otkrili ili mu se barem približili, moraćemo da uspostavimo dublji odnos sa slikom. Iz tog će odnosa, verujemo, proizići jedan nov oblik smisla, koji se više neće bazirati samo na fragmentarnosti ponuđenih poruka, već na koherentnosti značenja proizvedenoj u cirkulaciji tih poruka kroz lanac označitelja. Slika, shvaćena kao hipertekst, postaje onaj oblik naracije u kojem se podrazumeva 
koautorstvo njenog čitaoca: tako je postignut osnovni uslov za afirmisanje otvorenosti iz koje se pluralnost značenja slike/teksta izvodi kroz razotkrivanje njenih slojeva, njihovu razgradnju. U toj razgradnji anatomije slike počiva produkcija njenih značenja: "Tekst je pluralan, što ne znači da ima više značenja, nego da proizvodi mnoštvo značenja" 4 . Tekst je dakle shvaćen ne kao "objekt", već kao "prostor" između objekta i čitaoca/gledaoca - "prostor sastavljen od značenja koja se beskonačno umnožavaju i koja nemaju nijednu stabilnu tačku porekla, niti zatvaranja" ${ }^{5}$. Neograničeno ekstenzivan po svojoj prirodi, taj prostor je prostor intertekstualnosti - presek označavanja.

Reč je dakle o Ambasadorima. Delo Hansa Holbajna Mlađeg (Hans Holbein the Younger), iz 1533. godine, danas u londonskoj Nacionalnoj galeriji, u teorijskom smislu ima ultimativnu vrednost za analizu ontološkog statusa slike po sebi, tj. slike kao vizuelnog medija. Ono se danas, sa istorijskom distancom od skoro pet stotina godina od nastanka, može čitati i u ključu vizuelne predstave težnji nove, ujedinjene Evrope: delo nemačkog autora rođenog u Augsburgu, obrazovanog na iskustvu italijanskih majstora, nastalo je u Engleskoj tokom njegovog angažmana u visokim krugovima, i imalo je za sadržaj susret dvojice prijatelja Francuza, stranaca u Londonu, povezanih kako ličnim tako i zvaničnim razlozima u čijoj osnovi leži ideja očuvanja integriteta (prijateljstva/katoličke Evrope), a sve u trenutku kada istorijske okolnosti pružaju dovoljno razloga za zabrinutost $i$ sumnju u mogućnost ispunjenja takvih očekivanja.

U svojoj monografiji o Holbajnu, Helen Lengdon (Helen Langdon) ukazuje na podatak povodom Ambasadora da su muške figure na slici identifikovane posrednim putem, jer u autorovoj zaostavštini nisu ostali sačuvani nikakvi pripremni crteži za ovu sliku, niti je potpuno jasno kako je došlo do njene porudžbine. Muškarac sa leve strane prepoznat je kao Žan de Dentvil (Jean de Dinteville) na osnovu jednog crteža Žana Kluea (Jean Clouet), nastalog u isto vreme kada i Holbajnova slika. ${ }^{6}$ Ovaj miste-

4 Roland Barthes, From Work to Text, in: Art After Modernism: Rethinking Representation, eds. Wallis B., New York 1984, str. 169-174.

5 Burgin V., Re-reading Camera Lucida, in: The End of Art Theory: Criticism and Postmodernity, eds. Burgin V., London 1986, str. 73-92. Ovaj tekst je indikativan zbog genealogije binarnog kvaliteta slike u Bartovim ranijim radovima na polju semiološkog pristupa vizuelnosti, sa polazištem u pretpostavljenoj analogiji između "prirodnog jezika," s jedne strane, i svih ostalih sistema značenja tretiranih sa stanovišta lingvističke nauke, s druge strane. U tom smislu, Burgin uspostavlja istorijski razvoj bartovskog lanca binarnih parova: denotacija/konotacija (Fotografska poruka, 1961; Retorika slike, 1964), očigledno/tupo značenje (Treće značenje, 1970), studium/ punctum (Camera lucida, 1980).

6 Langdon H., Holbein, London 1993, str. 64. 
riozni Francuz bio je plemić iz Polisija (Polisy), domena u kome je posedovao svoj zamak (globus na donjoj polici pokazuje tu lokaciju). Za njega se zna da je bio imenovan ambasadorom u Londonu, u službi francuskog kralja Fransoa I (François I). Tamo je boravio od početka februara do novembra 1533. godine. Poup-Henesi (John Pope-Hennessy) ističe alegorijski karakter Holbajnove slike, upravo u vezi sa figurom Žana de Dentvila u kome vidi njenog naručioca: Holbajnova slika je prva u nizu od tri alegorijske predstave koje registruju tri prelomna trenutka u životu i karijeri ovog plemića. ${ }^{7}$ Ona se tiče odgovornosti koju je, kao diplomata svoje zemlje, preuzeo sa ciljem da - u trenutku kada je bračna afera na najvišoj političkoj instanci pretila Engleskoj raskidom sa katoličkim centrom u Rimu, aktuelnom engleskom vladaru Henriju VIII (Henry VIII) ekskomunikacijom, a Evropi razvojem ukupne nestabilnosti - obavi misiju čiji bi se konačan cilj sastojao u prevazilaženju raskola i potencijalnih nemira, kao i u obnavljanju integriteta katoličke Evrope. To je dakle bio jedan izuzetno značajan i moralno obavezujući zadatak, zbog čega je Dentvil imao dovoljno razloga da poruči vizuelni dokument o svojoj misiji u Engleskoj, i to od tada jednog od najcenjenijih slikara na Ostrvu.

Ostale dve slike Poup-Henesi dovodi u vezu sa Holbajnovom. Prva od njih je delo nepoznatog autora, verovatno Flamanca, i po svojoj kompozicionoj strukturi i političko-religioznom simbolizmu indikativna je i za interpretaciju Ambasadora. ${ }^{8}$ Ona je biblijska po tematici (Mojsije i Aaron pred faraonom) i njena narudžbina datira iz 1537. godine, perioda u kome se nad porodicom Dentvil nadvila senka nove krize, koja je rezultirala progonom Žanove braće iz Francuske. Slika predstavlja grupu muških figura u čijem centru prepoznajemo Žana de Dentvila u ulozi Mojsija, dok pred figurom faraona (čije crte lica otkrivaju aktuelnog francuskog kralja Fransoa I) pokazuje prstom na svog brata Fransoa (François de Dinteville), biskupa iz Oksera (Auxerre), u ulozi Arona, pravednog sveštenika. Naličje slike otkriva, pored identiteta još dve figure u pozadini - preostala dva Žanova brata: Gijoma (Guillaume) i Gošea (Gaucher), i moto

7 Pope-Hennessy J., The Portrait in the Renaissance, London 1966, str. 252.

8 U svojoj analizi ove slike, Entoni Blant (Anthony Blunt) ističe da je naručilac bio Žanov brat, Fransoa de Dentvil, za koga se pretpostavlja da je tom narudžbom želeo da uspostavi pandan sa slikom svog brata, izvedenom četiri godine ranije (dakle sa Ambasadorima), kako bi ove dve slike visile na zajedničkom zidu. Blant takođe ukazuje na pogrešnu atribuciju ove slike u osamnaestom veku, jer je utvrđeno da osoba za koju se ranije mislilo da predstavlja njenog autora, izvesni Feliks Kretjen (Félix Chrétien), nije ni bio slikar po vokaciji, nego sekretar biskupa od Oksera, tj. Fransoa de Dentvila. Pogledati u: Blunt A., Art and Architecture in France 1500-1700, Harmondsworth, Middlesex 1973, str. 115. 
porodice koji otkriva značenje biblijske parabole. "Sreća je pratilac vrline" je poruka koja treba da ukaže na zasluge pravednog biskupa iz Oksera, i na nadu i očekivanja porodice Dentvil da će, u slučaju pretnji trojici Žanove braće izgonom iz Francuske, pravda zajedno sa milošću i presudom Fransoa I pobediti ljubomoru i okrutnost glavnog inicijatora te afere - vojvotkinju od Etampa (Étampes). Druga (i poslednja slika u tom “triptihu”), iz 1544. godine, odnosi se na rasplet porodične afere Dentvilovih i oslikava ponovno uspostavljanje njihove reputacije i stabilnosti, a sve nakon povratka Fransoa de Dentvila iz progonstva u Francusku 1542. godine. Autor slike je Primatičo (Primaticcio) koji je u to vreme radio baš u Polisiju. Ovde je, kroz vrlo jasnu aluziju na konačnu pobedu Dentvilovih nad košmarima sudbine, predstavio Žana de Dentvila samog, odevenog u klasično odelo antičkog heroja, u ulozi svetog Đorđa kome pod stopalima leži glava savladane nemani. Ona je manifestna i ceremonijalna $u$ smislu kojim njen poručilac potvrđuje rezultate svojih moralnih napora uloženih u cilju prevazilaženja svih prethodnih konflikata. Posmatrane zajedno (Poup-Henesi navodi da su sve tri bile zajedno instalirane u Dentvilovom zamku u Polisiju) one objedinjuju težnju svog patrona da jezikom slike i u alegorijskom ključu ostavi dokaz o ozbiljnosti situacija koje su ga okupirale, ali pre svega o njegovoj ličnoj veri u pozitivan ishod tih situacija. Druga osoba na Ambasadorima identifikovana je kao Žorž de Selv (Georges de Selve), još jedan Francuz, biskup od Lavura (Lavour), Dentvilov prijatelj i budući francuski ambasador u Veneciji. Pretpostavlja se da je njegova šestonedeljna poseta Londonu imala značaj diplomatske i moralne podrške Dentvilu. Zanimljivo je međutim da Poup-Henesi dovodi u pitanje i sam naziv slike upravo zbog činjenice da, za razliku od Dentvila, Žorž de Selv, tokom boravka u Engleskoj, nije bio u statusu ambasadora (titula ambasadora biće mu dodeljena tek godinu dana kasnije, povodom njegovog zadatka u Veneciji), zbog čega ovaj autor smatra da naslov Holbajnove slike može dovesti u zabunu. $^{9}$

Obe figure su nam naizgled otvorene pogledima koje upućuju sa slike: muškarac levo usmerava ga malo udesno (ulevo u odnosu na nas), dok se drugom zenice nalaze skoro na sredini beonjača, možda tek uz blagi nagoveštaj pomeranja ulevo (udesno u odnosu na nas). Holbajnovi ambasadori ne gledaju jedan u drugog. Oni, iako jedan pored drugog, simetrični u svom rasporedu u odnosu na kredenac u sredini koji čini njihov zajednički oslonac, ne komuniciraju direktno. Obojica su okrenuti prema nama, ali ne gledaju ni u nas - samo izgleda kao da nas gledaju direktno u oči, ali njihov pogled je negde drugde. Njihov pogled je za-

9 Pope-Hennessy J., op. cit., str. 245. 
držan - unutra. Hladan, ravnodušan i dalek, njihov pogled otkriva uzdržanost i opreznost. Ne pretpostavlja nikakvu razmenu sa nama. Bez zahteva za reciprocitetom, on samo produbljuje distancu između "njih" i "nas". Distanca je neophodan uslov da bi se podigla fiktivna pregrada između slike i izvan-prostora: jer ono što ih odvaja od nas jeste aura individualizovanog prisustva koju nose i kojom štite svoju intimnost od posmatrača. ${ }^{10}$ Bliskost koju nam slika nudi lažna je - ispunjenost verodostojno izvedenim predmetima pruža iluziju stvarnosti: gotovo na dohvat ruke, spremni smo da poverujemo kako su ti predmeti pravi i kako ih je lako dotaći, uzeti sa slike, posedovati. Haptičko je ipak pobeđeno optičkim: razoružani uspostavljenom distancom odustajemo od te pomisli. Zatvoren, poput njihovih tela u odeći koja ih štiti poput oklopa, njihov pogled čini ih večno nemim i nepristupačnim, odvojenim od nas i među sobom.

I pored izrazito taktilnog kvaliteta slike, ta granica je još naglašenija privilegovanim distanciranjem glavnih protagonista. Razlog za to leži i u činjenici da su Ambasadori za svog naručioca imali, pre svega, kultni status. Slika nije bila namenjena pogledu javnosti, njena izložbena vrednost svesno je supstituirana privatnom željom naručioca da bude postavljena u njegovom ličnom "panoptikonu", u kuli koja je činila deo njegovog privatnog poseda: "To što postoji neka prepreka i izvesna investicija da bi se ona savladala, konstitutivni su momenti jedne ekonomije kojoj podležu kako diskurzivno, tako i skopičko polje. Na taj način se težište moći izmešta na stranu onih koji kontrolišu uklanjanje/postavljanje neke prepreke, dajući im istovremeno i privilegovano mesto u polju produkcije smisla. (...) Ta razlika između kultne i izložbene vrednosti znači i prelazak sa jedne ekonomije pregrade na neku drugačiju ekonomiju koja pretpostavlja i prestrukturiranje polja moći"11. Ako je pogled ambasadora intravertan i izmiče predstavljanju, ako je trebalo da postavi pregradu između slike i njenih posmatrača, gde je onda lociran Pogled na slici Ambasadori?

\section{Ideja kompromisa}

Oni su ih povezali skupa da bi ih povezali sa zakonom normalne upotrebe. Oni su povezali, spojili, a spriječili ono dijaboličko, ono što bi se odnosilo na duplicitet bez parnosti, nečeg duplog bez para. Oni su povezali da bi ograničili jedno uznemiravajuće raščlanjivanje. To je uslov da bi se opravdala istina za koju oni vjeruju da mora postojati

na slici.

Žak Derida ${ }^{12}$

10 Berger J., Ways of Seeing, London 1972, str. 97.

11 Čekic J., Presecanje haosa, Beograd 1998, str. 77.

12 Derida Ž., Istina u slikarstvu, Nikšić 2001, str. 345. 
Uočavati protivrečnosti - tragati za njima u slici, izvlačiti ih na videlo, upoređivati ih i ustanoviti simptomatičnim za prirodu slike - značilo bi prihvatiti ambivalentan, dvopolni identitet Ambasadora, onu konstruktivnu dvosmislenost koja se nameće i traži da bude verifikovana u punom obimu. Vraćamo se zakratko na početak: dve su dakle muške figure ovde predstavljene - dvojica prijatelja, jedan "par". Par, parnost ili sparivanje: duplicitet ipak ne pretpostavlja apsolutnu povezanost - podrazumeva i razdvajanje, mogućnost raščlanjivanja, svođenja broja na cifre, “jedan i jedan su dva”. Prostor između njih je možda njihov jedini zajednički oslonac, ali je izvesno i njihov hijatus koji zauvek izoluje jednog od drugoga. Nisu njih dvojica ti koji nose autoritet posredničke, "diplomatske" uloge koja im je dodeljena - ono što zauzima prostor između njih, sredina koja ih istovremeno spaja i razdvaja, taj dvospratni kredenac u sredini, to je metaforičan prostor njihove misije: "Posrednički način je u sredini između dvaju drugih koje skuplja i dijeli u sebi, prema jednoj strukturi obavijanja koju je teško ispostaviti”'13.

Rešenje problema koji se, shodno tome, odnosi na konkretan motiv ove posete, objasnilo bi i razloge jukstapozicije dvojice muškaraca na Holbajnovoj slici. Poup-Henesi iznosi stav da je, pre nego iz zajedničkih profesionalnih, diplomatskih razloga, povezanost ove dve figure na slici rezultat njihove upletenosti u veliku religioznu krizu tog doba. ${ }^{14}$ Do takvog zaključka dolazi pre svega na osnovu amblematskog karaktera Holbajnove predstave. On najpre ističe ambivalentnu prirodu Selvove posete Londonu, koja je bila kako zvanična (jer ga je za to ovlastio francuski kralj lično) tako i tajna, jer je vesti iz Londona i rezultate misije francuskog poslanstva trebalo zadržati u tajnosti od religioznih opozicionara. $U$ vezi s tim navodi se da su, svojim društvenim angažmanom, i Dentvil i Selv pripadali frakciji umerenih reformatora, za razliku od francuskih klerikalnih ekstremista, čiji je predvodnik bio Monmorensi (Montmorency). Lautu sa slomljenom žicom, koja se nalazi na donjoj polici između dveju figura na Ambasadorima, i koja tradicionalno simbolizuje neslogu, raskol (ono što će nam u daljoj analizi slike pomoći da definišemo i ideju rascepa, ali u sasvim drugom smislu), Poup-Henesi vidi kao amblem koji direktno upućuje na religioznu pozadinu njihovog angažmana u Londonu.

Konačnu potvrdu teze o religioznoj konotaciji slike, kojom se dovode u sumnju i čisto privatni razlozi jukstaponiranja dveju figura u okvire konvencionalno prihvaćene predstave takozvanog prijateljskog portreta, Poup-Henesi izvodi na osnovu relacija

13 Ibid., str. 309.

14 Pope-Hennessy J., op. cit. 
koje ova lauta uspostavlja sa ostalim, promišljenom kombinatorikom ukomponovanim simbolima na slici. Ti simboli uvode u naš narativ konkretnu istorijsku figuru, čiji su projekti na nivou podrivanja ustanovljenih ideja katoličke crkve predstavljali inicijalnu kapislu u rušenju i reorganizaciji čitavog jednog religioznog, društvenog, političkog i kulturnog sistema. Radi se o Luteru (Martin Luther). Otvorena knjiga pored laute predstavlja nemački himnarijum koji sadrži upravo njegov prevod pohvalnih pesama u Slavu Božiju (Veni Creator Spiritus) i početak njegovih čuvenih "Deset zapovesti", zakucanih na vrata vitenberške katedrale 1517. godine. Postoje još dve važne indikacije religioznog karaktera slike. Prva se odnosi na donji nivo slike: pod na kojem stoje figure dekorisan je tako da sve upućuje na činjenicu da je Holbajn svesno izveo repliku mozaičke ornamentike oltarskog poda iz Vestminsterske opatije (Westminster Abbey) u Londonu. ${ }^{15}$ Druga se odnosi na gornji nivo slike: $u$ krajnjem levom uglu (u odnosu na nas), jedva vidljivo i na margini izuzetno dekorisane zelene zavese, pojavljuje se predstava Hristovog raspeća. Ovakva amblematska konstelacija upućuje Poup-Henesija na nesumnjivu religioznu konotaciju Holbajnovih Ambasadora i on u njoj vidi "svečan manifest zagovaranog verskog kompromisa"

Istina ili ne, to nam još uvek ne daje pouzdan zaključak o preciznom religioznom smislu predstave: naprotiv, samo doprinosi njenoj ambivalentnosti, tim pre što ni sâm autor slike nije imao potpuno i konačno definisan stav po pitanju svoje religiozne opredeljenosti. Zna se da je jedan od razloga njegovog napuštanja Bazela, grada za koji je vezan rani period njegove umetničke karijere, ležao upravo u preobražaju kojim je nadirući protestantizam tamo ubrzavao promene, između ostalog, i u sferi kulturne politike, i praktično prisiljavao članove slikarskih gildi ne samo da pristupe novom pokretu već i da pristanu na propagirani ikonoklazam. Na religiozno slikarstvo se dakle sve više gledalo sa neodobravanjem, a to je, za umetnika poput Holbajna, značilo gubitak posla i shodno tome - egzistencijalnu nesigurnost. Pitanje slike, fundamentalno za opstanak slikarstva u doba reformacije, nametnulo se kao ključni motiv njegove odluke da odlaskom iz Bazela sebi pronađe neko tolerantnije mesto za život i rad. To utočište biće za njega London, u koji prvi put dospeva 1526. godine zahvaljujući uticajima i vezama koje je dotle

\footnotetext{
15 Videti: Langdon H., op. cit., str. 62. ("The floor-pattern is close to that of England's only mosaic floor, by the shrine of Saint Edward the Confessor in Westminster Abbey, and perhaps signifies nationalism and religion effectively combined")

16 Pope-Hennessy J., op. cit., str. 250.
} 
ostvario u humanističkim krugovima. ${ }^{17}$ Poup-Henesi navodi da su razlozi Holbajnove religiozne dileme bili čisto empirijske prirode: Holbajn, iako je gajio simpatije prema reformaciji i bio nenaklonjen papstvu, odbijao je da prihvati nov crkveni obred sve dok se ne obezbedi zadovoljavajuće objašnjenje prirode tog obreda. ${ }^{18}$ Krug humanista sa kojim je Holbajn dolazio u kontakt pre dolaska u Englesku obezbedio mu je uslove za opšte obrazovanje - primenom tog znanja on će definisati i atmosferu u Ambasadorima. Zato je važno distancirati se od čisto religiozne konotacije, kakvu nam nudi prethodno tumačenje, i pokušati da u njenom prožimanju sa humanističkim, naučnim, profanim idealima epohe dešifrujemo smisao slike za koji mislimo da ima opravdanja.

Ako je, kako tvrdi Poup-Henesi, ideja crkvene reforme zaista činila okosnicu Ambasadora, u kom odnosu prema toj ideji stoje ostali predmeti na slici? Ovo pitanje inspirisano je, pre svega, prirodom predmeta koje uočavamo na dvema policama. Izvesno je da se radi o objektima-instrumentima koji se dovode u vezu sa naukom. Oni, s obzirom da zauzimaju centralni položaj u slici, na kredencu između dvojice prijatelja, neizostavno, u standardnom ikonografskom ključu, referiraju na njihova interesovanja - određuju ih dakle kao ljude od znanja, obrazovane, intelektualce. Pored već opisanih, religiozno konotiranih, na policama se uočavaju predmeti profanog/naučnog karaktera. U opisu koji nalazimo kod Šejke (Leonid Šejka) ${ }^{19}$ saznajemo da se radi o hronometrijskim, astronomskim i navigacionim instrumentima (s tom razlikom što bi cevasti otvori u desnom uglu donje police predstavljali futrolu za neki muzički instrument, verovatno drvene flaute, ili korice za note). Evo kako izgleda taj opis:

"Astronomske instrumente Holbajn je nabavio kod Kratcera, astronoma i majstora instrumenata, svog prijatelja, koga je četiri godine ranije portretirao. Na gornjoj površini stola, pored nebeskog globusa, vidimo cilindrični sunčani časovnik. Do njega leži kvadrant i poliedrični sunčani časovnik sa magnetskim kompasom izrađen od slonove kosti. Zadnji instrument desno je torkvetum, služio je za određivanje položaja nebeskih tela. Polukružni poklopac na torkvetumu sa tegom od olova, nazvan semizis, služio je za merenje visine zvezda. Na polici dole leži zemaljski globus, rad Šenera iz Nirnberga iz 1523. godine, sa ispisanim političkim zonama, od kojih su neke bile i Dintevi-

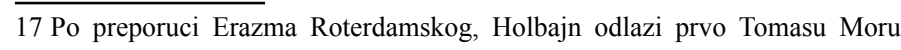
za koga će izvesti grupni portret porodice Mor (1526); Ambasadori (1533) nastaju na početku Holbajnovog drugog boravka u Londonu, koji traje od 1532. pa sve do smrti 1543. godine.

18 Pope-Hennessy J., op. cit.

19 Šejka L., Traktat o slikarstvu, Beograd 1964, str. 176-186. 


\section{MARKO STAMENKOVIĆ}

lov domen. Ispred globusa je poluotvorena matematička knjiga Apijanova, štampana 1527”20.

Imamo dakle situaciju u kojoj izloženi instrumenti i knjige odražavaju dizajn samog kredenca tako da oni na gornjoj polici ukazuju na proučavanje neba i nebeskih tela, dok objekti na donjoj polici više ukazuju na svakodnevni, zemaljski kontekst. Knjiga koju Šejka ovde pominje identifikovana je kao Nov i detaljan uvod u sve trgovačke proračune Pitera Apijana (Peter Apian), izdata 1527. godine. To je indikativan podatak jer govori kako o korenima kapitalističkog duha na Zapadu tako i o svesti modernog evropskog čoveka da ideološke temelje materijalističke tradicije i savremenog ekonomskog života nađe upravo u veri. Marvin Peri (Marvin Perry) u tom smislu upućuje na Protestantsku etiku i duh kapitalizma (1904) nemačkog sociologa Maksa Vebera (Max Weber). Ističući da je kapitalizam postojao i pre reformacije, u načinu poslovanja trgovačkih banaka po srednjovekovnim italijanskim i nemačkim gradovima, Veber je branio tezu po kojoj je protestantizam dao poseban dinamizam kapitalizmu jer je, za razliku od katolicizma, dao versku saglasnost za zarađivanje novca i način života poslovnog čoveka: "Poslovni ljudi protestanti verovali su da imaju versku obavezu da stiču novac, a vera im je ulila samodisciplinu da u tome uspeju. Uvereni da je prosperitet božji blagoslov, a siromaštvo njegovo prokletstvo, kalvinisti su imali duhovni podsticaj da vredno rade i da izbegavaju lenjost"21. Holbajn je stoga proizveo jednu modernu predstavu ekonomske samosvesti, nešto poput manifesta političke ekonomije individualnog spasenja, koja je u individualističkoj religioznosti videla svoje pravo i čvrsto zaleđe i dala još jednu potvrdu ideji kompromisa u Ambasadorima. ${ }^{22}$

Opisani predmeti na gornjoj polici su instrumenti kojima se mogu odrediti sati i datumi. Radi se dakle o objektima čija je funkcija u identifikaciji vremena. Još ranije pomenuti globusi imaju takođe identifikacionu ulogu - njima se određuje prostor (prostor neba i prostor zemlje). Upućivanje na elementarne kategorije vremena i prostora nije slučajno. Ono predstavlja uvod u kosmičku dimenziju smisla Holbajnove slike. Ono takođe predstavlja i sintezu dve vrste pojavnog sveta - vidljivog i nevidljivog, pogledu dostupnog i nedostupnog, zemaljskog i nebeskog, ljudskog i božanskog. Uvođenje takvih opozicija najprirodnije je inkorporirano u celokupni (binarni) kvalitet slike i komplementarno je do sada postavljenim tezama. Predmeti na kredencu odnose se na intelektualna interesovanja i profesionalne i prak-

20 Ibid., str. 176.

21 Peri M., Intelektualna istorija Evrope, Beograd 2000, str. 84.

22 Bodrijar Ž., Simbolička razmena i smrt, Gornji Milanovac 1991, str. 163. 
tične aktivnosti portretisanih; oni predstavljaju kulturni kompendijum toga doba. Zajednički efekat ovih predmeta (naučno i religiozno konotiranih) sastoji se u tome da demonstrira bliske veze dvojice predstavljenih muškaraca sa: (1) naučnom i obrazovnom renesansnom zajednicom, odnosno sa humanističkim intelektualnim pokretom, koji se smatrao visoko progresivnim u to doba, i (2) religioznim pokretom, koji u tom trenutku trpi posledice protestantskih zahteva za korenitim preobražajem crkvenog sistema. Oni, objedinjeni na istom mestu, povezuju međusobno suprotstavljene tendencije epohe i tek u tom smislu predstavljaju potpun "svečani manifest kompromisa" (koji je definisan kod Poup-Henesija, ali u drugačijem i, verujemo, nedovoljno opravdanom smislu). Želja za skladom odražena je tako u simboličkom prisustvu laute - ona, iako konotira religiozni raskol, takođe konotira poziv i potrebu za prevazilaženjem tog raskola u duhu prosvećenog evropskog humanizma. Himna, upućena Gospodu na nemačkom, sa stranica Luterovog prevoda Veni Creator Spiritus, stoji rame uz rame sa ovakvim težnjama - ona je pohvala jednom, zajedničkom Bogu, koji je spreman da prihvati sve hrišćane koji su, dok u njegovu milost veruju, isto toliko nalik jedni drugima koliko se i razlikuju.

Ambasadori su slika koja, uviđajući razlike, čineći ih očiglednim (čak i na čisto denotativnom nivou, čak i za one koji su, nesposobni da čitaju, bar sposobni da gledaju, za one koje hrišćanska tradicija poznaje kao Biblia pauperum), poziva na uvažavanje razlika, pomirenje i toleranciju; ona nije "portret dvojice prijatelja" - ona je jedinstveni portret institucije prijateljstva. Ambasadori tako nadilaze strogu žanrovsku klasifikaciju: Holbajn uspostavlja koordinate dvojnog portreta ukrštanjem koncepta kompromisa/sinteze ("prijateljski portret") i koncepta kontrasta (razdvajanja/udvajanja), kao neke vrste udvojenog individualnog portreta ("indiferentnog portreta") u čijoj osnovi leži ideja usamljenosti, ili, još preciznije, ravnodušnosti:

"Dostojanstveno, ukočeno držanje Dentvilovo i de Selvovo pokazuje, uprkos njihovim približenim laktovima koji počivaju na stolu prekrivenom ćilimom, pre dva odvojena portreta na jednoj slici, a manje jedinstveni, dvojni portret, "portret prijateljstva". Oni su odvojeni glavnim dešavanjima slike, postavljenim po centralnoj, vertikalnoj osi. (...) Ipak, ovde su izdvojenost i usamljenost (egzistencijalna manje nego intelektualna) okićeni reprezentativnim dragocenim inventarom renesanse (inventarom koji ima kumulativno dejstvo, sa namerom da pokaže povezanost dvojice ambasadora sa naučničkom i 


\section{MARKO STAMENKOVIĆ}

umetničkom progresivnom elitom renesanse), divnom odećom i retkim predmetima“"23.

Kanonizovanje svesti o individualizmu može se prihvatiti i kao recidiv onih fundamentalnih tendencija rane renesanse kojima su uspostavljene nove, antropocentrične vrednosti modernog doba. Činjenica je da se tada rađa jedna u osnovi svetovna kultura, usredsređena na čoveka, potvrdu njegove ličnosti i sticanje priznanja za njegova individualna dostignuća u oblastima koje su premašivale usko shvaćene teološke zadatke srednjovekovne dogmatike. Ovo je vodilo preorijentaciji renesansnog čoveka sa nametnute smernosti u krugovima hrišćanskog bratstva ka radoznalosti pojedinca obrazovanog na temeljima klasičnog učenja kojim je uspeo da izgradi kritički stav prema instituciji crkve i uvede na scenu individualizam kao rezultat sopstvenih napora za duhovnim preobražajem. S druge strane, u kontekstu verskog raskola u XVI veku, kao ekvivalent intelektualnom individualizmu renesanse, reformacija je nametala ideju o verskom individualizmu proizišlu iz stava o jednakosti ljudi i duhovnoj jednakosti svih vernika, a suprotnu ustaljenoj crkvenoj hijerarhiji i razlici između običnih ljudi i klera. Ovaj, u osnovi buntovan i samouveren stav, promovisao je veru kao ličnu i unutrašnju stvar kojom je verifikovan direktan odnos između svakog pojedinca i Boga, bez svešteničkog posredovanja. Na taj način, protestantski duh je - razvojem unutrašnjih verskih sposobnosti pojedinca i njegove autonomne pozicije u verskim pitanjima - učvršćivao unutrašnju sigurnost i samopouzdanje novog, modernog Evropljanina. Protestantsko isticanje individualne svesti i individualnog tumačenja Svetog pisma promovisalo je dakle slobodu svesti i uvelo na evropsku scenu zahtev za tolerancijom verskih shvatanja. Holbajnovi Ambasadori, sintezom predstavne mnogoznačnosti religiozne i profane aktuelnosti, proklamuju upravo princip tolerancije u vidu reprezentativnog slikarskog manifesta baziranog na usklađenim kontrastima.

\section{Smrt i zavesa}

Depresija je skriveno lice Narcisa, lice koje će ga odnijeti u smrt mada tada ne zna da se divi obmani. Govor o depresiji odvešće nas ponovo u močvarni kraj narcističkog mita.

Julia Kristeva ${ }^{24}$

Ovo udvajanje (koje je istovremeno odvajanje, razdvajanje, rascep) uvodi nas polako u konačni stadijum ikonografske analize

23 Merenik L., Ideološki modeli: srpsko slikarstvo 1945-1968, Beograd 2001, str. 111.

24 Kristeva J., op. cit., str. 11. 
Ambasadora. Šta bi mogao biti razlog tom osećanju indiferentnosti koje opterećuje sadržaj ove slike? I šta zaista možemo podrazumevati pod rascepom koji se u ovoj slici provlači od samog početka, između polova njene esencijalne dvosmislenosti, a sada potvrđuje kao konačni rezultat te ravnodušnosti, tog "praznog pogleda" dvojice prijatelja, tog slatkog zadaha melanholije?

Kristeva, povodom Holbajnovog Mrtvog Hristosa (1522), postavlja pitanje: "Da li je bogočovjek bio tužan, to jest obuzet smrću, zato što je seksualan, žrtva seksualne strasti?" 25 Uvođenje diskursa o seksualnosti moglo bi nas, barem u ovom trenutku, odvesti na sasvim drugu stranu od onoga čemu smo rešeni da damo završni oblik. Kristeva međutim usmerava na "patološki nenormalnu patnju s onu stranu nejasnog erotizma", i plasira tezu o očiglednosti Hristovog bola kroz Pasiju (kao onaj oblik religiozne strasti koji se u hrišćanskoj ikonografiji dovodi u vezu sa Hristovim mučenjima) da bi sugerisala stanje osamljenosti koje "kao kompoziciona činjenica slici daje najvišu melanholičnu težinu"26. U toj osamljenosti, shvaćenoj kao odvojenost, napuštenost, izolovanost strasnog tela, ona otkriva i mogućnost sudelovanja posmatrača u slici smrti, "u smrti kao suštinskom znaku ljudskosti", koja je "način da se vidi čovječanstvo sa distance, do smrti".

Predstava smrti je rezultat ultimativne transpozicije pogleda posmatrača u nevidljivi drugi svet. Ta preobražena nevidljivost zavodi pogled i upućuje mu poziv za učestvovanje u drami Smrti. Holbajnova publika, gledajući mrtvo Hristovo telo, gleda smrti pravo u lice - iako je ne može videti; Holbajn nam predlaže "viziju čovjeka podređenog smrti, čovjeka što prihvata Smrt, koju upija svim svojim bićem, uključujući je ne kao uslov svoje slave ni kao posljedicu svoje grešne prirode, već kao krajnju bit desakralizovane stvarnosti koja je temelj novog dostojanstva" ${ }^{27}$. Renesansni čovek, suočen sa desakralizovanom stvarnošću, sa njenom krajnjom biti, dostiže spokoj novog dostojanstva, ali i razočarenje: “(...) Nezamislivi vidokrug i nevidljiva smrt Holbajnu se postavljaju kao glavno iskušenje novom čovjeku i besumnje samom umjetniku. Zar vam ništa ne izgleda poželjnije, jer se vrijednosti ruše, jer ste sumorni?" 28

U Holbajnovoj analizi moralizma smrti u vezi sa opštim shvatanjem života i sudbine, smisao Kraja nije fiksiran (baš kao ni njegov oblik u Ambasadorima): on se kontinuirano premešta sa originalnog, hedonističkog (u kome je, analogno horacijevskom

25 Kristeva J., op. cit., str. 137.

26 Ibid., str. 138.

27 Ibid., str. 145.

28 Ibid., str. 149. 
carpe diem, predstavljao jasan poziv na konzumaciju životnih zadovoljstava, na uživanja u svakodnevici, koliko god ona bila prolazna) na potpuno suprotan, moralistički (koji je dakle u strogom sholastičkom maniru propagirao smernost, pokornost, uzdržanost od tih istih zadovoljstava i pokajanje). Promenljiv smisao smrti nosi u sebi dozu ambivalentnosti kojom ideja kratkog života (vita brevis) odstupa od prethodnih jednoznačnosti i otvara mogućnosti višesmislenog tumačenja, u zavisnosti od subjektivnog "ugla posmatranja". Izvesno je da, koji god dictum da je bio u pitanju, prisustvom lobanje na slici ostaje na snazi ideja prolaznosti. U kontekstu Ambasadora ona se ispoljava u odnosu između "nevidljive" slike lobanje date u anamorfozi i vidljivog ostatka slike opterećenog materijalnošću predmeta koji generalno ukazuju na domete ljudskog znanja. Holbajnova slika, u tom smislu, može imati i pesimističan i optimističan ton. Ona može predstavljati: (1) izraz upozorenja na ispraznost i uzaludnost ljudskih napora uloženih u sticanje znanja (kao i rezultata tog znanja), s obzirom na značaj koji se pridavao svesti o kratkotrajnosti života i spremnosti na nadolazeću smrt; (2) odstupanje od konvencionalnog značenja u smislu poruke da se “(...) život ispuni stvaralaštvom i najvećim unutrašnjim bogatstvom, bez obzira na ono nepoznato sa one strane zelene zavese (u pozadini slike)" 29 .

Ali prezir prema znanju mogli su ispoljiti samo oni koji su to znanje posedovali, koji su vladali njime i koji su uspostavljali norme sopstvenog ponašanja i delovanja na osnovama tog znanja, razvijajući strategije intelektualnog i kulturnog razvoja. Intelektualac međutim, koliko god bio kritičan prema otvorenom polju postojanja, nikada nije gubio svest o onostranom, o postojanju "iza zavese", o konačnoj istini u pozadini ovozemaljskog materijalnog sveta. Fragmentarna predstava Hristovog raspeća, više sakrivena nego otkrivena u gornjem levom uglu Ambasado$r a$, marginalizovan je, ali značajan nagoveštaj te ideje - ona, čak i u svom nenametljivom prisustvu treba da podseća i upućuje na neprikosnoven smisao kraja. Ona je pozicionirana iza leđa glavnih protagonista slike jer je svedena na objekat promišljanja, večne kontemplacije, na citat prošlosti koji treba da formira narativ budućnosti. Takođe, ona je indikativna za ustanovljenje Ambasadora kao introspektivnog portreta, u kome se kontemplativnost podrazumeva u obliku narcisoidnog samoposmatranja, a činjenica da se (raspeće) nalazi sa iste strane slike kojoj pripada i Žan de Dentvil mogla bi naročito da ukazuje na njegovu introvertnu, kontemplativnu prirodu melanholika. Shodno tome, zanimljivo je i dovođenje u vezu ove figure sa trostrukom slikom smrti (raspeće - lobanja - medaljon na Dentvilovoj ka-

29 Šejka L., op. cit., str. 176-186. 
pi). Semjuel (Edgar R. Samuel) podseća na zaslugu Meri Harvi (Mary Hervey) koja je, detektovanjem medaljona u vidu lobanje na kapi Žana de Dentvila, ponudila tezu o lobanji kao njegovom ličnom heraldičkom obeležju i time dovela enigmatičan anamorfički element i ideju smrti u direktan odnos sa konkretnom ličnošću sa slike. ${ }^{30}$ Prihvatimo li ovu teoriju, onda se - takvim umnožavanjem slike smrti - lobanja koja referira na lični grb Žana de Dentvila potvrđuje kao još jedna manifestacija motoa memento mori. Ali zašto bi jedan ambasador imao više razloga da referira na smrtnost od drugog? Dentvil se navodno često žalio na svoja melanholična raspoloženja, a to bi mogao biti i razlog zbog kojeg su mu tokom jednog takvog perioda poseta i prisustvo prijatelja bili naročito važni. Okruženog amblemima smrti i zagledanog u sebe, Holbajn predstavlja Dentvila kroz naglašeno narcisoidnu prirodu njegovog portreta, koja je samo paravan za pravi razlog njegove koncentracije, paravan iza kojeg se pomalja slutnja o neumitnosti sopstvenog kraja. Ako Kristeva, koja Mrtvog Hristosa vidi kao izraz Holbajnovog slikarskog minimalizma, uporište melanholije nalazi u nepredstavljivom, gde onda nalazimo sliku Smrti u Holbajnovim Ambasadorima? ${ }^{31}$ To dakle nisu ni raspeće, ni medaljon na Dentvilovoj kapi, ni lobanja data $\mathrm{u}$ anamorfozi. To je slika koja ostaje sakrivena iza pogleda Narcisa, slika koja provocira time što ostaje zauvek sakrivena iza zelene zavese Ambasadora. Slika Smrti je slika pod velom koja nudi poslednji i presudni element za rešenje zagonetke Ambasadora, zagonetke vidljivog i nevidljivog.

\section{Zaključak: vidljivo i nevidljivo}

Siguran sam da ću se pogledati u ogledalo i da u njemu ništa neću videti. Ljudi me uvek nazivaju ogledalom, a kada se ogledalo pogleda u ogledalo, šta ima da vidi?

Endi Vorhol ${ }^{32}$

Sadržaj Ambasadora nudi nam dve vrste pojavnosti, koje u najjednostavnijoj podeli možemo čitati kao predmetnu i nepredmetnu ili kao realističku i apstraktnu.

Iz minuciozne izvedbe detalja, iz onoga što bi se moglo okarakterisati kao tendencija za dostizanjem simulacije do stepena

30 Samuel R. E., Death in the Glass - A New View of Holbein's Ambassadors, Burlington Magazine, CV, 1963, str. 436.

31 "Holbajnov hromatski i kompozicioni asketizam prevodi nadmetanje forme sa ni izbjegnutom niti uljepšanom smrću, već fiksiranom u minimalnoj vidljivosti, u njenoj krajnjoj manifestaciji što stvara bol i melanholiju." (Kristeva J., op. cit., str. 150.)

32 Warhol A., Filozofija Endija Vorhola, Od A do B \& Nazad, Beograd 1995, str. 13. 
gotovo fotografskog realizma u slikarstvu, zaključujemo da se radi o precizno konstruisanoj i jasno definisanoj materijalnoj $v i-$ dljivosti predmeta (setimo se da je to bila jedna od privilegija onih renesansnih slikara koji su upravo svojom sposobnošću za vernim opisivanjem materijalne strane predmeta, naročito odeće kao izraza bogatstva portretisane osobe, sticali pravo na angažman u najvišim, pa i vladarskim, patronažnim krugovima). Ovi su predmeti dakle prisutni (predstavljivi) time što su svojom materijalnošću "vidljivi" i što pružaju mogućnost identifikacije imenovanjem, čime nesputano ulaze u narativ slike. Džon Berdžer (John Berger) pristupa Holbajnovoj slici upravo sa stanovišta njenog predmetnog sadržaja i njegovog vrhunski postignutog materijalnog, taktilnog kvaliteta. Činjenica da je "ono što izdvaja uljanu sliku od svake druge vrste slikarstva njena naročita sposobnost da predoči opipljivost, teksturu, sjaj, solidnost onoga što oslikava", mogla bi zvučati stereotipno da Ambasado$r i$ ne stoje na početku primene nove slikarske tehnologije. Medijem u kojem je izvedena (uljana tehnika), ova slika odražava aktuelnosti svoga doba, među kojima se najviše ističe drugačija artikulacija vrednosti robe i njene kupovne moći. Predstavljeni predmeti (neki od njih sasvim retki i skupoceni), simulirani do tančina, nude se svojim taktilnim vrednostima posmatraču kao realni objekti, kao objekti koji se mogu posedovati. ${ }^{33}$ Potencijal uljane slike da ostvari veći utisak predmetne iluzije od bilo koje starije slikarske tehnike korespondira sa njenom sposobnošću da preorijentiše posmatrača od isključive upotrebe čula vida u smeru translacije slike u jezik čisto taktilne senzacije. Berdžer čak ide dotle da podređuje prisustvo dvojice muškaraca $i$ objekata između i oko njih dominaciji materijalne, strukturalne prirode predstavljenog sadržaja. U tom bogatstvu i raznolikosti materijala (krzno, svila, metal, drvo, somot, mermer, hartija) Berdžer vidi reference na sve one zanatske prakse uključene $u$ njihovu realnu proizvodnju i primenu. Ove reference su, pored evidentne tehničke virtuoznosti u izvođenju, Holbajnu poslužile kao okosnica njegove strategije citatnosti $i$ simulacije koja mu je omogućila slikarsku aproprijaciju potrošačkih proizvoda i njihovu konačnu reprodukciju i prevođenje u sadržaj slike. Izrazita simulacija materijalnosti u Ambasadorima dokaz je dakle kulturnih i ideoloških pozicija svoga vremena: ideja bogatstva, materijalne raskoši i raznolikosti, inkorporirana je u uljanu sliku kao dokaz novog, dinamičnog tipa bogatstva (za razliku od onog koje je u prethodnoj slikarskoj tradiciji imalo za cilj da simbolizuje statičan društveni ili državni poredak) koje je našlo svoju potvrdu u kupovnoj moći novih društvenih formacija. Tako je sama slika trebalo da demonstrira želju za onim što se može

33 Berger J., op. cit., str. 88-91, 94-97. 
kupiti novcem, a otuda i želju svog vlasnika za opipljivošću i posedovanjem njenog konkretnog sadržaja.

S druge strane, suprotno evidentnom, formiranom, predmetnom, materijalnom i realističkom sadržaju slike, uočava se i "slika u slici”, drugačija od prethodno opisane. To je fragmentarna, izobličena, nejasna i "nevidljiva" slika, koja se odupire bilo kakvom imenovanju i koja kao da provocira posmatrača svojim "ćutanjem" i njegovom nesposobnošću da prepoznat ali nepoznat/ neidentifikovan predmet definiše i sagleda na način kojim mu to uspeva sa ostatkom slike. Ona je rezultat izobličenja, svesno inkorporiranog u telo slike, koje joj daje kvalitete deformisanog, apstraktnog, nepredmetnog.

Posmatrač je dakle prinuđen da sliku posmatra ne kao celovitu vizuelnu strukturu, vidljivu u svim svojim fragmentima, nego kao napuklu/rascepljenu strukturu, istovremeno vidljivu i nevidljivu. Ona je celovita samo u meri u kojoj briše granicu između unutrašnjeg i spoljašnjeg prostora slike, čime subjekt i objekt posmatranja ulaze u zajednički, isprepleteni prostor gledanja. Kao posledica ovakvog rascepa u strukturi slike nastupiće konačni rascep: rascep gledajućeg subjekta u polju posmatranja. Prva slika od posmatrača zahteva konvencionalan pristup: ona se obraća oku frontalno pozicioniranog gledaoca, naviklog na ustanovljen transfer pogleda direkcijom centralne geometrijske perspektive do tačke nestajanja. Posmatrač te slike je geometrijski, centrirani (centrični) posmatrač koji (još uvek) živi u iluziji da objekat svog pogleda može držati pod kontrolom svog oka. Njegov status je stoga uslovno aktivan i neprikosnoveno "ličan" - njegov pogled gospodari objektom kome je usmeren. Druga slika, apstraktna slika u realističkoj slici, od posmatrača u početku ne zahteva ništa - upravo zato što je na prvi pogled "nevidljiva”. Ona je učaurena u telu slike, njeno konačno utočiste je rupa u realnom, predmetnom poretku sveta slike. Ali sva njena snaga leži upravo u tome: da se kao "rupa u realnom", kao "prazno mesto slike", probije u njen prvi plan i privuče pogled posmatrača, da ga ukroti (lakanovski dompte-regard). Time što izaziva posmatrača, koji ne pristaje na anomalije u sebi podređenom vizuelnom polju, upire mu prstom u oko, bode ga i iritira, izbacuje iz udobne renesansne fotelje i traži od njega da učini nešto, da se pomeri ili da proba da nekako skine veo sa te nevidljivosti. Jer ova slika jeste slika pod velom i zahteva novog, mobilnog, decentriranog posmatrača, sposobnog da pod onim što ga privlači svojom nevidljivošću, sakrivenošću pod velom, otkrije nešto. I

nađe šta? Ništa, jedno veliko Ništa sakriveno pod velom.

U Lakanovom diskursu veo (ili zavesa) ispostavlja se za fundamentalnu sliku čovekovog odnosa prema svetu i savršeni primer analize situacije želje - veo, u materijalnom smislu, predstavlja 
otelotvorenje prostora između one veze između Subjekta koji gleda i Objekta koji je gledan, i koja potvrđuje činjenicu da predmet želje uvek leži iza vidljivog sveta pojavnosti, u kome se pronalazi samo simbol želje, jedno veliko ništa: odsutnost je slika na velu, jer sa prisustvom vela ono što se nalazi ispod, kao nedostatak koji je skriven od pogleda i time nedostupan oku, teži da bude realizovano kao slika, kao vizuelna predstava. Zavesa je idol odsutnosti, u njoj posmatrač inkarnira svoje osećanje ovoga ništa koje je samo simbol (ili falus, sve dok se u psihoanalitičkom kontekstu tiče kastracionog kompleksa). To je situacija ekvivalentna onoj na početku Mišiminog (Yukio Mishima) Mornara koji je izneverio more u kojoj glavni junak, dečak Noboru, posmatrajući kroz rupicu u zidu svoju majku dok se presvlači, u sobi pored, otkriva fatalnu istinu viđenja: nedostatak falusa nije za njega samo anatomski regulator polne razlike, to je i uvod $u$ beskonačnu opsesiju situacijom manjka čijem se prevazilaženju, od tog trenutka, čitavog života fantazmatski teži. Veo istovremeno otkriva i skriva, on posmatrača navodi da "fantazira o 'pravoj stvari' i da priželjkuje da je vidi" ${ }^{34}$ iako iza njega ne postoji ništa, ili u stvari postoji odsutnost (absence), jedno Ništa kao prazno mesto želje, Ništa koje se uvek krije iza objekta želje.

Uvodeći granicu vidljivosti u prostor komunikacione mreže između slike i posmatrača, Holbajn remeti gledaočev pristup vizuelnoj predstavi. Konvencionalno shvaćen pogled, uslovljen direkcijom centralne geometrijske perspektive i direktnim, pravolinijskim sudarom oka sa sadržajem slike, onemogućava posmatraču da fragment, kojeg on prepoznaje kao mrlju, vidi u njegovom punom obliku. "Senka" je u Ambasadorima bačena pravo u lice posmatraču: njegovu pažnju, zasićenu poretkom predstavnog sveta predmeta, počinje da privlači misteriozan, izobličen detalj, koji kao da lebdi u donjem delu slike, zbunjuje posmatrača i, na neki način, kvari celovit doživljaj predstavljenog sadržaja. Tako ovaj predmet "grubo razbija heraldičku kompoziciju i zamagljuje deo mozaičkog poda" ${ }^{35}$, a kada se konačno ukaže na mogućnost njegovog dešifrovanja korektnim načinom posmatranja, nevidljiva slika počinje da izranja. Taj zamagljeni fragment koji je u "senci" sâme slike, njena mrlja, biće identifikovan zauzimanjem odgovarajućeg, iskošenog ugla posmatranja

kao anamorfičan predmet - lobanja data $u$ anamorfozi.

Termin anamorfoza (grč. ana-morphosis, preobražaj, preinačenje), po optičkim zakonima, odnosi se na unakaženo nacrtanu

34 Garber M., Vested Interests. Cross-dressing \& Cultural Anxiety, New York 1993. Uporedi sa: Garber M., Šik od Arabije: transvestizam, transseksualizam i erotika kulturnog prisvajanja, Ženske studije 2/3, Beograd 1995, str. 162184.

35 Langdon H., op. cit., str. 19. 
sliku nekog predmeta, ali tako da izgleda onako kakva treba da je kad se gleda sa izvesne tačke (optička anamorfoza), ili odbijanjem od pogodnog ogledala (katoptrična anamorfoza) i kroz brušena stakla (dioptrična anamorfoza). ${ }^{36}$ Anamorfička slika je znači slika koja izgleda normalno samo kada se posmatra iz neke određene perspektive ili kroz neko preobražavajuće optičko sredstvo. Renesansni umetnici bili su često fascinirani takvim perspektivnim distorzijama i uključivali su ih u svoje slike. Smatra se da je anamorfičku, "veštačku" perspektivu otkrio Leonardo da Vinči (Leonardo da Vinci). Njegov Atlantski kodeks (Codex Atlanticus, 1487) sadrži dve skice u kojima se eksperimentiše ovom tehnikom i koje pokazuju Leonardovo interesovanje za radikalne forme perspektive. Jedna predstavlja lice deteta, a druga ljudsko oko. Ove slike izgledaju kao da su široko razvučene po horizontali, ali ako se posmatraju sa strane izgledaju precizno i jasno. Bilo je potrebno ispuniti nekoliko zahteva da bi se ove slike ispravno videle. Slika se mora posmatrati sa fiksirane tačke gledišta koja je na istoj horizontalnoj osovini kao i centar slike. Ova tačka mora biti pod izvesnim uglom u odnosu na ravan slike. Ako posmatračevo oko vidi sliku sa ove tačke, $i$ pritom samo jednim okom, slika će se pojaviti u željenoj formi. Ako se u odnosu na sliku promene ugao ili rastojanje doći će do izobličenja.

U svojoj studiji o Ambasadorima, Meri Harvi je, poput mnogih drugih kritičara, zagovarala tezu po kojoj je lobanja u središtu donjeg prednjeg plana Ambasadora izobličena refleksijom $u$ iskrivljenom ogledalu, i zahteva posmatranje iz krajnjeg desnog ugla kako bi bila ispravno sagledana. Ova situacija je vrlo dobro opisana kod Šejke. Pozivajući se na stariju literaturu o Holbajnovim Ambasadorima, Šejka u svom Traktatu o slikarstvu navodi tezu o kinetičkom posmatranju pri čemu bi se samo jedan ugao posmatranja (u uslovima izlaganja kodifikovanog pravilima centralne geometrijske perspektive) eliminisao u korist sukcesivne, multiplicirane percepcije izobličenog predmeta na slici i otkrivanja njegovog "realnog" izgleda, sve u zavisnosti od (1) pozicije slike u prostoru i (2) kretanja posmatrača. Ako je ova slika zaista bila postavljena u Dentvilovom zamku na stepeništu jedne kule, onda je po Šejkinim rečima “(...) penjući se stepeništem, posmatrač mogao da vidi sliku odozdo u velikom skraćenju, tako da se naslikana scena na slici nije mogla percepirati, sem žućkaste blješteće lobanje. Penjući se dalje do jednog odmorišta, gde je slika bila postavljena i odakle se mogla frontalno posmatrati, posmatrač bi doživeo promenu, lobanja je tada iščezavala i pretvarala se u neprepoznatljiv izduženi predmet. A kada bi se penjanje produžilo i bacio pogled odozgo na sliku,

36 Vujaklija M., Leksikon stranih reči i izraza, Beograd 1980, str. 44. 


\section{MARKO STAMENKOVIĆ}

oblici života na slici bi se ponovo rasplinuli i lobanja bi se opet videla, bez deformacije" ${ }^{37}$.

Ovo preovlađujuće stanovište međutim nije i jedino, i naišlo je na osporavanje među kritičarima, od kojih treba istaći Semjuela $^{38}$ i Baltrušaitisa (Jurgis Baltrušaitis). ${ }^{39}$ Sistem optičke anamorfoze funkcioniše tako što zahteva od posmatrača izbor tačke posmatranja, ali uz rizik da kao neminovni rezultat tog izbora uvek dođe do situacije poništenja. To znači da se zauzimanjem iskošene, neortodoksne pozicije gledanja fragment dat u izobličenju pojavljuje kao uobličen, jasan i vidljiv, ali se istovremeno poništava ostatak slikane površi novim izobličenjem, preseljenim sa fragmenta na ostatak slike. Inverzija ugla posmatranja uvodi sukcesivnu anamorfozu i u toj kinetičkoj igri vidljivost je stalno žrtvovana nevidljivosti. Posmatrač slike je time prisiljen da poveruje u to da se "realno" strukturira oko nečeg što ne postoji, oko praznog mesta, oko Ničega (psihoanaliza upravo potvrđuje tu činjenicu - Realno je, za Lakana, prazna kategorija). Semjuel zato uvodi drugu opciju, i predlaže objašnjenje koje ne odustaje od frontalnog posmatranja slike, ali zahteva pogled kroz staklenu cev. ${ }^{40}$ Argument za ovakvu tvrdnju nalazi u podatku iz istorijskog kraljevskog arhiva: radi se o dnevniku nekog mladog nemačkog plemića koji je prilikom posete dvoru Elizabete I (Elisabeth I) početkom XVII veka opisao i svoje uzbuđenje pred portretom kralja Henrija VIII u kraljičinim apartmanima $u$ Vajthol palati (Whitehall Palace). U vezi sa tim portretom, on ističe da je bio tako vešto izveden da je kraljevo lice, kada se posmatralo posebnim optičkim sredstvom, izgledalo duže od celog tela. Semjuel dovodi u vezu izobličenu lobanju na Ambasadorima sa ovim, hronološki bliskim, portretom jer smatra da u to vreme nije mogao biti jedinstven po navedenoj karakteristici, već da je njegovo izvođenje upravo podrazumevalo upotrebu naročitog sočiva kroz koje su i lobanja na $A m b a-$ sadorima i, kasnije, lik Henrija VIII dobijali potpuni oblik. Ako je to tačno, onda je posmatrač mogao da vidi lobanju iz pozicije koja je direktno ispred slike (a ne više iz krajnjeg desnog ugla). Najverovatnije je da se radilo o cevi od duvanog stakla debelih zidova, koju je bilo jednostavno koristiti, čak i u svakodnevnim prilikama, i čija površina poseduje relativno visok optički kvalitet. Na osnovu jednog detalja u Holbajnovom portretu Georga Giza (George Gisze) iz 1532. godine - cevasta vaza od duvanog stakla - Semjuel ističe da je ta vrsta stakla bila poznata u ranom

37 Šejka L., op. cit., str. 176-186

38 Samuel E. R., op. cit., str. 436-441.

39 Baltrusaitis J., Anamorphic Art, New York 1977. (Anamorphoses, ou perspectives curieuses, Paris 1955)

40 Samuel E. R., op. cit., str. 439. 
XVI veku (on čak tvrdi da se radi o venecijanskom kristalu (cristallo), tipu bezbojnog stakla naročito popularnom početkom XVI veka). Staklena cev koja dozvoljava identifikaciju lobanje ima i tu dodatnu prednost da ulazi u samu kompoziciju slike time što je, na određeni način, transformiše: posmatranjem lobanje kroz cev, u tački ukrštanja njihovih dijagonala, po sredini slike u vertikalnoj liniji formiraju se tri sferična objekta u nizu (od nebeskog, preko zemaljskog globusa, sve do lobanje); dijagonalno položena, kao pandan suprotno usmerenoj dijagonali deformisanog predmeta, ova cev čini integralni deo slike kojim se pogled posmatrača usmerava naviše, ka Dentvilovoj glavi, fokusnoj tački slike.

Kada je reč o metodi koju je slikar usvojio da bi izveo anamorfozu u Ambasadorima, Baltrušaitis odbija mogućnost Holbajnovog direktnog posmatranja prave lobanje kroz izobličujuće staklo, i predlaže najjednostavnije rešenje: sistem linearne rešetke. Ona je najpre omogućavala prenošenje preliminarnog, precizno izvedenog crteža lobanje u okvire druge rešetke (u kojoj bi bilo izvedeno željeno izobličenje), a zatim, kvadrat po kvadrat, konačno kopiranje distorziranog crteža. ${ }^{41}$ Grinevejev (Peter Greenaway) film Crtačev ugovor (The Draughtsman's Contract) indikativan je u tom smislu jer kritikuje tradicionalni oblik viđenja: on preuzima linearnu rešetku za osnovni instrument kritičkog modela kojim se dovodi u pitanje validnost renesansnog geometrijskog režima slike kao ultimativne reprezentacije viđenja. I dok je renesansna perspektivna logika pružala sve uslove za isticanje centralnog dela slike i njene glavne radnje u prvi plan, sporedni detalji su funkcionisali na račun tih zahteva, ali u sopstvenu korist: iako je status fragmenta, poput amorfne lobanje u Ambasadorima, marginalizovan pozicioniranjem van centralnog događaja kompozicije ili optičkim izobličenjem, on - jednom prepoznat - postaje presudan element u konačnom i celokupnom efektu slike. On narušava striktni model gledanja, razbija ga, proširuje i dekonstruiše, "inficira" čitav narativ da bi uveo mogućnost sagledavanja sveta iz drugog ugla, i bukvalno "iz druge perspektive". U prilog ovom "heliocentričnom" diskursu zanimljivo je insistiranje na paradigmatskom poređenju Holbajnove lobanje sa Suncem: ono, "koje je uslov vidljivosti svega, ali je samom oku nedostupno jer svaki pokušaj oka da direktno vidi uslov vidljivosti završava u belom slepilu", ispostavlja se kao mesto skopičkog subjekta na slici jer je "skopički subjekt uvek prisutan na slici, ali je njegovo prisustvo nedostupno oku - zapravo to mesto je uslov mogućnosti vidljivosti ali je

41 Baltrusaitis J., op. cit. 
samo nevidljivo". ${ }^{42}$ Tom mestu u lakanovskom diskursu pripada termin scotoma (slepo polje) iz kojeg slika uzvraća pogled svom posmatraču, a koje je sâmom posmatraču nevidljivo. U pitanju je ono što će rani perceptualisti, na primer Merlo-Ponti (Maurice Merlo-Ponti), nazvati fundamentalnim narcizmom svakog viđenja kada opisuju situaciju ukidanja granica između posmatrača i posmatranog (u međusobnom ukrštanju njihovih pogleda dijalektikom vidljivosti i nevidljivosti): smisao narcisoidnog ogledanja ne sastoji se jedino u uživanju u sopstvenoj ogledalnoj slici (ospoljavanju sebe), već i u povratnoj reakciji kojim to spolja gleda mene, tj. u činjenici da me moj sopstveni lik, $\mathrm{u}$ ulozi fantoma-zavodnika, istovremeno posmatra iz ogledala, sa mesta koje je sâmo nevidljivo. Operišući po principu uvlačenja, hvatanja posmatrača u ono što gleda, aktivnost posmatrača ekvivalentna je njegovoj pasivnosti, i on biva elidiran (rascepljen) u polju posmatranja - posmatrač i slika vrše međusobnu razmenu, tako da više nije moguće tačno ustanoviti ko gleda a ko biva gledan.

U svom tumačenju anamorfoze, Lakan (Jacques Lacan) se nadovezuje na Merlo-Pontijevu tezu o fundamentalnom narcizmu svakog oblika viđenja kao rezultatu ukidanja granice između posmatrača i onog što je posmatrano, i revidira je u kontekstu konkretnog primera - Holbajnove slike Ambasadori. Kao i Bartova "nota o fotografiji," i Lakan izvodi svoju tezu o pogledu najpre iz osećanja začudnosti koju u njemu izaziva misteriozan, iskošen objekat u prednjem planu između dve figure. Imajući $\mathrm{u}$ vidu da čitav niz predmeta u slici - grupisanih po principu klasične sistematizacije znanja - ukazuje na simboliku životne prolaznosti (vanitas), i da se radi o predstavi iz vremena uspona svesti o subjektu i razvoja optičkih istraživanja, Lakan izvodi zaključak da je Holbajn, paradoksalno, učinio vidljivim poništenje subjekta (the subject as annihilated). Tragajući za funkcijom pogleda, on se distancira od preliminarne simbolike po kojoj je anamorfičku sliku doveo u analogiju sa tetoviranim falusom (koji daje jasnu sliku samo u erekciji) i ukazuje na pogled kao takav (the gaze as such), koji se, kao u ovoj slici, otkriva svojom zbunjujućom i ekstenzivnom funkcijom. Na kraju zaključuje : "Ova je slika jednostavno ono što i svaka, klopka za pogled ( $a$ trap for the gaze). Za svaku sliku važi da, upravo dok tražite pogled u svakoj od njenih tačaka, on nestaje". Ovde imamo na delu opis konfrontacije subjekta i objekta pogleda u trenutku njihovog rascepa: subjekat pogleda je uhvaćen, "zarobljen" od strane svog objekta i vraćen nazad. Refleksija tog pogleda shvaćena je kao zamka za pogled. Za Lakana, anamorfička lobanja predsta-

42 Stojanović B., Prilog kritici libidinalne ekonomije lokalne umetnosti, Druga godišnja izložba Centra za savremenu umetnost, Beograd 1997. 
vlja Pogled, koji je u svakom drugom slučaju nevidljiv. Drugim rečima, pogled - da bi se pojavio na slici - mora biti podvrgnut metonimijskom obrtu. Ovaj "fantom", falički duh, funkcioniše dvojako: ne samo što čini vidljivim nevidljivi pogled, već kao slika lobanje aludira na smrtnost. Smrt je ultimativni podsetnik na granice saznanja. Slika fantoma odražava posmatrača, ali posmatrača u njegovom budućem stanju. Slika podmeće "zamku za pogled" time što (1) reprezentuje pogled i (2) iznenađuje i objektifikuje posmatrača na nivo posmatranog objekta.

Slika lobanje u Ambasadorima tajnovito izranja iz konteksta onoga što istovremeno izaziva i negira, a to je pojam humanitas, predstavljen predmetima koji u ovoj slici epohe predstavljaju i simbole vanitas-a. I sama Holbajnova slika nastoji da reprezentuje i da se suprotstavi onome što Merlo-Ponti naziva „fundamentalnim narcizmom svakog viđenja“. U okviru slike, predstavljeni predmeti menjaju svoje značenje od simbolične ispunjenosti do upozoravajuće smrtnosti. Pridružena pojava lobanje u sceni Ambasadora provocira momentalni utisak poniznosti kod posmatrača, jer on iznenada suočava sopstvenu smrtnost sa uzaludnošću ljudskog postojanja i napora. Postoje takođe tumačenja koja dopunjuju prethodno. Ako izbegnemo ona koja, baveći se etimologijom lobanje na nivou lokalnih termina (francuskog $i$ nemačkog) pokušavaju da igrom reči prebace smisao u kontekst dosetki, ${ }^{43}$ onda se ne suočavamo više sa lobanjom samo kao okultnim simbolom ili amblemom imaginarnog (smrti), već i sa njenim prisustvom u realnom poretku: ona, shvaćena kao telo $u$ prostoru, baca senku na površinu poda i zahteva od posmatrača da, u Holbajnovoj precizno izvedenoj realnosti slike, distorziju takođe prihvati kao znak da realnost, onako kako je čula opažaju, mora biti posmatrana "ispravno" da bi otkrila svoje puno značenje. Drugim rečima, lateralnost pogleda ekvivalentna je stavu da frontalno prepoznavanje izgleda stvari nije dovoljno. $\mathrm{Na}$ koji dakle način donosimo zaključak o realnom prisustvu lobanje u poretku stvari sveta slike? Supstitucijom realnog, kojom se jedna slika stvarnosti nadomešta drugom, izobličenom, "nevidljivom". Jer ultimativno saznanje, ono koje se tiče Kraja, počiva u nevidljivom: nemoguće je videti sopstvenu smrt, i stoga predstava lobanje stoji na onoj granici između života i njegove suprotnosti kojom, kroz anamorfozu, uvodi radoznalo oko u prostor paradoksalne, "nemoguće" predstave koja postaje evidentna.

43 Cranmer (crâne mère [fr.], prazna lobanja), aluzija na kenterberijskog nadbiskupa Tomasa Kranmera koji je poništio brak između Henrija VIII i Katarine; ili Holbein (hohl bein [nem.], sveta kost), aluzija na prezime samog autora slike; videti u: Samuel E. R., op. cit., str. 436-441. 
Ono sa čim nas Ambasadori suočavaju jeste zauzimanje radikalno drugačije pozicije posmatranja. To posledično destabilizuje autoritet retorike mainstream-a, kao jednog ideološki zauvek ukalupljenog sistema vizuelnih poruka i otvara prolaze svim onim diskurzivnim praksama koje, zahvaljujući novouspostavljenom statusu i funkciji Pogleda u slici, doprinose novoj, kritičkoj i heterogenoj produkciji značenja. Holbajn suprotstavlja jedan ugao gledanja drugome, optičku (nelinearnu) perspektivu dominantnoj centralnoj geometrijskoj perspektivi, i jednog indoktriniranog, geometrijskog subjekta - drugačijem, skopičkom subjektu. Ambasadori ne zahtevaju više samo statičnog, fiksiranog i fokusiranog posmatrača, već i decentralizovanog, "ekscentričnog" posmatrača, koji bludi pogledom po slici tražeći mesto odakle ga ona spokojno posmatra. To je konačni uzrok rascepa gledajućeg subjekta pred ovom slikom i konačna potvrda njenog binarnog kvaliteta. To je i osnovni razlog zbog kojeg ovo Holbajnovo delo predstavlja radikalni pomak u shvatanju koncepta slike i smatra se izrazito modernim. Ono subvertira ne samo tradicionalni sistem gledanja, već razdire čitav jedan sistem vrednosti, dovodi ga u pitanje, ironizuje i sumnja u njega na jedan gotovo bezazlen način. Ne zaboravimo da je to epoha naučne revolucije koja je, upravo sistematskim posmatranjem (dakle posmatranjem) i eksperimentisanjem, otvorila put ka modernosti, dala smernice modernom duhu i jednu sliku sveta zamenila drugom. Skeptici poput Kopernika (Nicolaus Copernicus, 14731543) transformisali su dijagram fizičkog svemira, "svrgli Zemlju sa prestola" i raspršili ptolomejski model u paramparčad, da bi rekonstruisali racionalno zadovoljavajuću, heliocentričnu sliku univerzuma.

Ako kopernikansko izmeštanje Zemlje iz središta svemira, kao potvrdu univerzalne istine, metaforički posmatramo i kao afirmaciju univerzalne istine u slikarstvu, onda nije preterano ako na kraju ovog teksta zaključimo sledeće: izmeštanjem Holbajnovog posmatrača iz udobnosti fiksirane tačke opažanja, njegovim pomeranjem, decentriranjem njegovog pogleda, učestvujemo u još jednom (istorijskom) pomeranju kojeg postajemo svesni upravo $\mathrm{u}$ trenutku gledanja slike Ambasadori. To je pomeranje pogleda na svet, pomeranja pogleda kao oblika radikalnog pomeranja iz blokirane tačke sveta u tačku koja oslobađa ali i pomeranja iz političkog i društvenog statusa quo. Zbog takve mogućnosti pomeranja kao mogućnosti promene još uvek imamo i (moramo imati) razloga da verujemo u mogućnost drugačijeg sveta i drugačijeg poimanja slike sveta - sasvim drugačijeg od onog u kojem želi da nas, poput zarobljenika, zadržava konzervativna, samodovoljna, "patriotska" kultura jednog okorelo centralističkog, tvrdoglavo frontalnog, i neprikosnoveno pravovernog ("straight") pogleda na svet. 


\section{MARKO STAMENKOVIĆ}

\section{LITERATURA:}

Miščević N. i Zinaić M., Plastički znak - zbornik tekstova iz teorije vizualnih umjetnosti, Rijeka 1981.

Baltrusaitis J., Anamorphic Art, New York 1977.

Berger J., Ways of Seeing, London 1972.

Blunt A., Art and Architecture in France 1500-1700, Harmondsworth, Middlesex 1973.

Bodrijar Ž., Simbolička razmena i smrt, Gornji Milanovac 1991.

Bonitzer P., Slepo polje, Beograd 1997.

Foster H., Vision and Visuality, Seattle 1988.

Burgin V., The End of Art Theory: Criticism and Postmodernity, London 1986.

Čekic J., Presecanje haosa, Beograd 1998.

Derida Ž., Istina u slikarstvu, Nikšić 2001.

Garber M., Vested Interests. Cross-dressing \& Cultural Anxiety, New York 1993.

Garber M., Šik od Arabije: transvestizam, transseksualizam i erotika kulturnog prisvajanja, Ženske studije 2/3, Beograd 1995.

Kristeva J., Crno sunce. Depresija i melanholija, Novi Sad 1994.

Lakan Ž., XI seminar - Četiri temeljna pojma psihoanalize, Zagreb 1986.

Lakan Ž., Spisi, Beograd 1983.

Langdon H., Holbein, London 1993.

Merenik L., Ideološki modeli: srpsko slikarstvo 1945-1968, Beograd 2001.

Peri M., Intelektualna istorija Evrope, Beograd 2000.

Pope-Hennessy J., The Portrait in the Renaissance, London 1966

Samuel E. R., Death in the Glass. A New View of Holbein's Ambassadors, Burlington Magazine, CV, 1963.

Uspenski B., Leva i desna strana u umetnosti ikona, Škola iz Tartua, Treći program Radio Beograda, Beograd 1979.

Vujaklija M., Leksikon stranih reči i izraza, Beograd 1980.

Wallis B., Art After Modernism: Rethinking Representation, New York 1984.

Warhol A., Filozofija Endija Vorhola, Od A do B \& Nazad, Beograd 1995.

Šejka L., Traktat o slikarstvu, Beograd 1964. 
MARKO STAMENKOVIĆ

\author{
Marko Stamenković \\ Ghent University, Belgium
}

READING THE AMBASSADORS

\begin{abstract}
FUNDAMENTAL NARCISSISM, SUBJECT ANNULMENT, AND YET ANOTHER SKETCH FOR A SELF-DESTRUCTIVE FUNCTION OF THE GAZE
\end{abstract}

\begin{abstract}
This text was born in the context of preliminary researches of the author in the field of picture analysis in which the function of the gaze itself is a decisive factor in the operation of annulment of the subject of gaze. The text starts from well known theoretic and art history interpretations of the picture The Ambassadors in which Hans Holbein the Younger, in the first half of the sixteeth century, counterposed not only optical nonlinear perspective against the dominant, central geometric perspective but also a geometric (linear, straight) subject to a different one: optical, ex-centric, scopic. The purpose of the paper is to wake up, once again, five centuries later, the static, fixated and focused observer (the symptom and main protagonist of a similarly static, fixated and focused culture of gaze) in order to take a radically different angle. Why? Because in displacing of the Holbein's observer from the status quo position (by de-centering his gaze, his optical removal from the comfort of a fixed point of observance and his physical moving) the de-centered, excentric observer is offered an opportunity to once again, and every time anew, get actively involved in the historic switch to a different culture of gaze. And a different culture of gaze here implies the kind of culture which, due to a constant overstepping of the limits of the un-culture of gaze, leads us to believe that a different world is possible and leads us to a different perception of the world of the picture and a different perception of the picture of the world - different from the one in which the conservative, atavistic, self-sufficient, patriarchal and "patriotic" culture keeps us prisoners of a hardened centralistic and stubbornly

frontal and undesputably orthodox (straight) view of the world.
\end{abstract}

Key words: (non)culture of gaze, annulment of the subject, narcissism of looking, Holbein 